\section{EDITH's Editions Mediate Finnish Classics for Contemporary Readers}

Finns have learned to demand that music is performed by top level orchestras and to expect that art can be enjoyed in good museums under the guidance of professional guides. Literary classics, on the other hand, can be read from the first paperback that catches one's eye. It suffices that the right name appears on the cover and it does not matter what sources on which the text is based or even if the text partly remains obscure because of the missing annotations or contextualizing essays. In many countries with a long literary history, educated people expect that classic editions should be properly edited and contain the introductory essays and annotation that explain the old texts for modern readers.

The French have Bibliothéque de la Plèiade, a series of classic editions, whereas English literature can be studied by reading Norton Critical Editions and many other Anglo-American series. Swedish readers can read the Swedish Literary Society's (Svenska Vitterhetssamfundet) editions and in Germany readers have, among others, a new institute for textual criticism, Institut für Textkritik, founded in the 1990s.

The above-mentioned series and institutes differ from one another, but they all promote literary criticism, teaching and layperson reading in many ways. They all publish critical editions, i.e., editions that are based on a thorough survey and comparison of original sources, together with supplementary commentaries and annotations.

\section{Critical Editions in Finland}

Finnish scholars have been active in editing international literature and other documents from papyrus fragments to Biblical texts. Despite the active text-critical research in many disciplines from exegetics to philology, Finnish literature, however has only sporadically been published in scholarly editions. In Finnish-Swedish literature two extensive series have been completed: Finnish national poet J.L. Runeberg's (1844-1877) collected writings in 1933-2005, and senator and philosopher J.V. Snellman's (1806-1881) collected works in 1992-1999. In literature written in Finnish there are only two rather small series, both of which need fundamental revision. One is that of Finnish national writer Aleksis Kivi's (1834-1872) collected works edited in four volumes by E.A. Saarimaa and partly Viljo Tarkiainen in 1915-1919, and the other is Eino Leino's (1878-1926) Poems I-IV edited by Aarre M. Peltonen in 1961-1968.

The small number of critical editions of Finnish literature is partly a consequence of Finnish literature's relatively young age. It normally takes decades before a book is so highly canonised that it has the honour of being published as a critical edition. The need for a critical edi- 
tion likewise often depends on the age of the book. Since the new millennium, the pressure to edit critical editions of Finnish literature has grown, since the literary language and culture of works preceding the 20th century are becoming unknown to present-day readers. Many old, dialectical and foreign words together with allusions to works that were known when a book was written are no longer automatically familiar. Along with the explanations, critical editions open up access to the manuscripts and first editions of the works, which otherwise would not be within reach of the reader.

Fortunately, new Finnish scholarly edition projects have been recently began. For instance, scholarly editions of texts by Mikael Agricola, Anders Chydenius, Elias Lönnrot and Zacharias Topelius are in progress. These editions represent different kinds of corpuses and editorial emphases as well as different periods in Finnish culture. The collected works of Agricola (ca. 1510-1557), who laid the foundations of standard Finnish, emphasise linguistic analysis. The edition project of Lönnrot (1802-1884), the creator of the Finnish national epic Kalevala, compiles the whole correspondence of Lönnrot, i.e., over 5000 letters which are essential for the historical research of many disciplines from botany to medicine and translation history to folklore. The Chydenius (1729-1803) project consists of the collected writings of one of the most notable politician and enlightenment thinkers in Sweden-Finland, to- gether with Finnish and English translations of the original writings in Swedish. The collected works of the journalist and author Zacharias Topelius (1818-1898) led by the Swedish Literature Society in Finland, consists of all the main literary genres, ca. 15700 printed pages and over eight shelf-meters of manuscripts.

\section{EDITH - Critical Editions of Finnish Literature}

The Finnish Literature Society started last year a new research and publishing unit EDITH - Critical editions of Finnish literature. Its long-term objective is, as in the French Bibliothéque de la Plèiade, to create an ongoing series of critical editions of Finnish classics. Similar to the French Bibliothéque de la Plèiade, it will not be limited to one writer, but become a versatile series of editions that would be a standard source for researchers, teachers and other readers.

EDITH will start with critical editions of the collected works of Finland's national writer, Aleksis Kivi (1834-1872). The first work to be edited will be Kivi's comedy Heath Cobblers (Nummisuutar$i t$ ), a living classic originally published in 1864. Its editor-in-chief is Professor Jyrki Nummi.

EDITH's editions comprise the text of a work that has been carefully selected and edited together with supplementary commentary sections that shed light on the work's publishing history, reception, research traditions, as well as genre and linguistic features. More detailed expla- 
nations are provided in the annotations, which illustrate variants of the text and literary allusions and explain the meanings of words and concepts.

The editions of EDITH will be published both as traditional books and as open access online publications as in many editions project in the Nordic countries. Similar dual publishing practice is in use for instance in the Danish Søren Kierkegaard project, the Norwegian Henrik Ibsen project, as well as the Topelius project of the Swedish Literature Society in Finland.

Digital editions enable such comparison and search functions that would be difficult or impossible to adapt in printed books. In some international digital editions it is, for instance, possible to read the same passage of the first edition and of one or more manuscripts or to search for words in one book or in the whole oeuvre of the writer. Furthermore, one advantage of the digital format is that it includes facsimile material that is much easier and cheaper to publish on-line than in traditional books.

\section{Editing Aleksis Kivi}

Choosing Aleksis Kivi as the first writer for the EDITH editions was not diffcult, because Kivi was one of the central creators of Finnish literature. He is a living classic whose works have been read for 150 years and whose dramas are still popular in theaters. His language and the culture represented in his books, however, hamper understanding for a 21 st- century reader, which makes annotation necessary.

For an editor Aleksis Kivi is interesting for historical reasons. He wrote at a time when Finnish literature was in its formative stage and the Finnish written language was not yet established. Kivi's language is partly written in dialect and contains influences from Swedish.

Intertextually, Kivi is challenging for he used western literature in many ways that complicate recognising and understanding the intertextual relations of Kivi's books and other texts. Kivi knew western literature especially through Swedish translations; thus his literary allusions occur on many levels. Moreover, he consciously misquoted the Bible. Beside literary allusions, Kivi's works contain influences from oral folklore, such as folk poetry, proverbs and tales, which are difficult to ascribe to any single source.

Publishing history, reception and literary critics' writings offer an interesting corpus for text critics, literary critics, linguists and culture historians. The mere publishing history of Kivi's selected and collected works illuminates interestingly Kivi's canonisation and the development of Finnish literary culture. On a large scale, the cultural functions of the three important Kivi editions have proceeded in three phases from polishing to collecting and delivering (Saarimaa) and thereafter to explaining and contextualising.

In the first phase, when journalist, pedagogue, literary scholar and lexicographer B.F. Godenhjelm (1840-1912) 
posthumously edited Kivi's Selected Works I-II in 1877-1878, five years after Kivi's death, Finnish literature was young compared to literature written in Swedish and Kivi's canonisation process was just beginning. At that time it was considered important to revise Kivi's old-fashioned language and also otherwise make him presentable.

When linguist E.A. Saarimaa (18881966) edited Kivi's collected works forty years later, it was important to collect all of the writer's works for readers. Like Godenhjelm, also Saarimaa slightly modernised and harmonised Kivi's language but not as radically as Godenhjelm. Saarimaa was, for instance, much more sensitive to the Nurmijärvi dialect used in Kivi's books. It is revealing that in the first edition of Kivi's Heath Cobblers the main character Esko uses the verb kylpeä ('to bathe') in an erroneous form kylpösi; in Godenhjelm's edition he uses the standard language form kylpi, whereas Saarimaa makes him use the correct dialectal form kylpöi.

The cultural function of EDITH's forthcoming Kivi editions is to bring the original works to light, explain them in a literary context and make them comprehensible to modern readers. The digital publishing format also enables conveying Kivi's manuscripts to everyone. At the same time EDITH advances the practices of editing scholarly editions of Finnish literature in co-operation with other Finnish edition projects.

\section{EDITH's critical editions...}

... Mediate Finnish classics for contemporary readers

The pressure to edit critical editions of Finnish literature has grown since the turn of the millennium, because the language and culture of the classics from the 19th century are becoming unfamiliar to present-day readers.

... Bring treasures to light Critical editions bring rare first editions and treasures in the archives within everyone's reach. ... Promote translation, artistic direction and rendition Conveying original texts together with contextualising essays and detailed annotation advances professional translation, theatre direction, film adaptations, and performances.

... Endure from one generation to the next

Critical editions form basic research that is durable. Editions in a digital format can be flexibly adapted for various purposes and easily updated.

... Form the cornerstone of research Editions that bring together the research tradition and the latest research knowledge serve literary research and several related disciplines.

... Create new research opportunities Digital editions with their search functions enable many new ways of researching language and literature.

www.edith.fi/english/

\section{Sakari Katajamäki}

